\title{
STRATEGI PENGENALAN BAHASA INGGRIS PADA ANAK USIA DINI DI TK SANTA MARIA BANJARMASIN
}

\author{
Nadiya Ulya \\ nadiyaulya2@gmail.com \\ Pendidikan Islam Anak Usia Dini Fakultas Tarbiyah dan Keguruan \\ UIN Antasari Banjarmasin \\ Nor-Izzatil Hasanah \\ izhanorhasanah@gmail.com \\ Pendidikan Islam Anak Usia Dini Fakultas Tarbiyah dan Keguruan \\ UIN Antasari Banjarmasin
}

\begin{abstract}
This research discusses about the strategy of introducing English in the TK Santa Maria Banjarmasin, include in this research is: methods, media, materials and assessment . This research is descriptive qualitative, the subject of this research are 12 children from class A1 and 13 children from A2 and 1 English teacher in Santa Maria Banjarmasin. The data collected by using of observation, interviews, and documentation. The data analysis in this research used Milles and Huberman which was conducted interactively using data consisting of reductions, presenting data, and conclusion(coding). The results of research shoved every English teaching in TK Santa Maria Banjarmasin that appropriate in the learning process in accordance with the child's development, English development strategies that are equipped: 1) Learning methods used when carrying out activities introducing English methods such as singing , game, listen and repeat, questions and answer and make matches. 2) The media used are display media and worksheets. 3) The material introduces English to children in this school are family, animals, healthy food and Christmas. 4) The assessment used are observation, children product, conversation and anecdotes.
\end{abstract}

Keywords: Strategy, English, Early Childhood 


\begin{tabular}{|c|c|c|}
\hline \multicolumn{3}{|c|}{ Jurnal Warna : Jurnal Pendidikan Dan Pembelajaran Anak Usia dini. } \\
September 2020. Vol 05. No. 02 \\
\hline Received: Agustus 2020 & Accepted: Agustus 2020 & Published: September 2020 \\
\hline & Article DOI: $10.24903 / j w . v 5 i 2.525$ \\
\hline
\end{tabular}

\section{PENDAHULUAN}

Istilah PAUD kini begitu sering didengar atau dikenal di masyarakat, mulai dari anak-anak hingga orang dewasa, PAUD adalah pendidikan untuk anak yang berumur dari $0-6$ tahun, yang mana pada umur tersebut dapat disebut juga dengan masa golden age. Pada masa inilah anak harus diberikan stimulasi yang baik agar anak dapat mengembangkan kepribadian dan potensi secara maksimal sesuai dengan tahap perkembangan dan pertumbuhan anak, adapun tujuan dari stimulasi tersebut adalah agar anak siap untuk melanjutkan ke jenjang pendidikan selanjutnya (Helmawati, 2015:43). PAUD adalah suatu upaya pembinaan yang ditujukan kepada anak anak sejak lahir hingga usia enam tahun yang dilakukan melalui pemberian rangsangan pendidikan untuk membantu pertumbuhan dan perkembangan jasmani serta ruhaninya agar anak memiliki kesiapan dalam memasuki jenjang pendidikan lebih lanjut (UU No. 20 Tahun 2003) Oleh karena itu, PAUD menyediakan sarana untuk memberikan rangsangan kepada anak agar dapat mengembangkan kepribadian dan potensi secara maksimal, atas dasar ini lembaga PAUD perlu menyediakan berbagai kegiatan, sarana dan prasarana yang dapat membuat berbagai aspek perkembangan seperti kognitif, sosial, emosi, fisik motorik dan bahasa dapat berkembang. Bahasa Inggris adalah bahasa asing yang pada masa ini sangat penting untuk dipelajari, karena Bahasa Inggris adalah bahasa internasional yang mana bahasa inilah yang sering digunakan dalam segala bidang kehidupan, untuk mempermudah komunikasi dengan orang yang berada di negara lain, menjalin kerjasama, memperluas pergaulan dan untuk bersaing di dunia luas. Saat ini banyak anak pra-sekolah atau taman kanak-kanak yang juga belajar Bahasa Inggris sehingga dapat mengelompokkan mereka sendiri ke dalam kelompok very younger learners. Rentang usia anak yang berada di Taman Kanak-Kanak biasanya 4 sampai 6 tahun. Biasanya anak pada usia dini memiliki daya ingat yang sangat kuat dan cepat untuk menangkap sebuah pembelajaran baru karena otak anak masih fleksibel. Dalam pembelajaran Bahasa Inggris kematangan siswa di kelas tidak hanya ditentukan oleh usia, atau jenjang kelas mereka saja, tetapi juga faktor lain, seperti lingkungan yang berada di perkotaan atau perdesaan, budaya setempat,minat dan pengaruh orang tua (Kasihani K.E. Suyanto, 2007:15). Pengenalan Bahasa Inggris untuk anak usia dini terdapat pro dan kontra, pendapat yang pro dalam pengenalan Bahasa Inggris untuk anak usia dini, menurut Penfield dalam teori mekanisme otak (theory of brain mechanism) masa usia dini merupakan masa yang paling ideal untuk belajar bahasa selain bahasa ibu (bahasa pertama). Alasannya karena, pada usia dini otak anak masih plastis dan fleksibel, sehingga proses penyerapan bahasa lebih mulus. Selain itu, daya penyerapan bahasa pada anak berfungsi secara otomatis, karena pada usia yang lebih dari itu otak akan menjadi lebih keras, lambat dan kurang bisa menerima rangsangan bahasa, karena otak lebih siap dengan tugas yang lain (M.F Sri Ekonomi, 2007:3). Adapun yang kontra berpendapat dalam pengenalan Bahasa Inggris 


\begin{tabular}{|c|c|c|}
\hline \multicolumn{4}{|c|}{ Jurnal Warna : Jurnal Pendidikan Dan Pembelajaran Anak Usia dini. } \\
September 2020.Vol 05. No. 02 \\
\hline Received: Agustus 2020 & Accepted: Agustus 2020 & Published: September 2020 \\
\hline & Article DOI: $10.24903 / j w . v 5 i 2.525$ \\
\hline
\end{tabular}

untukoanak0usia dini salah satunya adalah masa kanak-kanak masa bermain, bahasa asing di anggap terlalu membebani mereka. Dengan adanya pro kontra tersebut dapat diketahui bahwasanya pada masa anak usia dini sangat bagus dikenalkan bahasa asing selain bahasa ibu, bahasa Ingris sebagai salah satu bahasa asing pertama yang harus dikenalkan kepada setiap individu termasuk anak usia dini, tetapi sebagai pendidik harus dapat membuat strategi pengenalan Bahasa Inggris semenarik mungkin sehingga anak tidak merasa terbebani dengan adanya pengenalan Bahasa Inggris tersebut. Berdasarkan hasil observasi dan wawancara dengan salah satu guru di TK Santa Maria Banjarmasin, Bahasa inggris ini termasuk ekstrakulikuler tapi tidak di luar jam sekolah, jadi kegiatannya dilaksanakan ketika jam pembelajaran sekolah, agar anak tidak perlu lagi menambah waktu untuk les di luar jam sekolah. Pembelajaran untuk mengenal Bahasa Inggris di TK Santa Maria Banjarmasin dilaksanakn satu minggu sekali untuk kelompok A dan B, sedangkan kelompok A dan B terbagi menjadi dua kelas A1 dan A2, B1 dan B2. Untuk guru yang mengajar Bahasa Inggris, gurunya memang dari lulusan Bahasa Inggris. Biasanya pengenalan Bahasa Inggris hanya dengan menggunakan metode dengar dan ulangi tanpa adanya pembiasaan sedangkan di TK Santa Maria Banjarmasin mengenalkan Bahasa Inggris dengan metode pembiasaan. Untuk penelitian lebih lanjut peneliti tertarik untuk meneliti proses pengenalan Bahasa Inggris untuk anak usia dini di TK Santa Maria, jadi peneliti termotivasi untuk mengadakan penelitian tentang "Strategi Pengenalan Bahasa
Inggris pada Anak Usia Dini di TK Santa Maria Banjarmasin"

Penelitian ini sejalan dengan yang dilakukan oleh Titin Kartinah (2018) dengan judul "Pengenalan Bahasa Inggris Melalui Metode storytelling Berbantu Media Gambar Pada Anak Usia 5-6 Tahun Di Tk Purnama Sukarame Bandar Lampung" Penelitian ini menyimpulkan bahwa anak usia dini memiliki masa yang peka terhadap sesuatu, segala macam aspek bahasa dapat dikenalkan kepada mereka, karena pada masa itu anak menyukai segala hal yang bersifat menyenangkan, maka pendidik harus berusaha untuk memberikan yang terbaik pada masa tersebut dengan memberikan strategi-strategi yang menyenangkan dalam proses pembelajaran.

Penelitian tentang ini juga pernah dilakukan oleh Yus Vernandes Uzer (2019) dengan judul "Strategi Belajar Bahasa Inggris yang Menyenangkan untuk Pendidikan Anak Usia Dini”. Penelitian ini menyimpulkan bahwa strategi bahasa Inggris yang menyenangkan adalah dengan metode yang dapat membuat anak termotivasi ,sehingga anak menyukai kegiatan yang dilakukan.

Kemudian penelitian yang dilakukan oleh Rizka Isnaani Putri (2018) "Peningkatan Penguasaan Kosakata Bahasa Inggris dengan Metode Bernyanyi pada Kelompok B Taman Kanak-Kanak Anak Sholeh Sukodono Sidoarjo". Penelitian ini menyimpulkan bahwa pengenalan bahasa Inggris dengan menggunakan metode menyanyi dapat meningkatkan kosakata anak dikarenakan bernyanyi merupakan kegiatan yang dekat dengan anak karena bersifat menghibur. 


\begin{tabular}{|c|c|c|}
\hline \multicolumn{4}{|c|}{ Jurnal Warna : Jurnal Pendidikan Dan Pembelajaran Anak Usia dini. } \\
September 2020.Vol 05. No. 02 \\
\hline Received: Agustus 2020 & Accepted: Agustus 2020 & Published: September 2020 \\
\hline & Article DOI: $10.24903 / j w . v 5 i 2.525$ \\
\hline
\end{tabular}

Diharapkan dalam penelitian yang di lakukan oleh penulis dalam penelitian dengan judul Strategi pengenalan bahasa Inggris untuk anak usia dini juga dapat memperoleh hasil yang memuaskan seperti penelitian terdahulu dan dapat berguna bagi guru dan peserta didik.

\section{METODE PENELITIAN}

Penelitian ini merupakan penelitian kualitatif deskriptif, subjek dalam penelitian ini adalah guru khusus Bahasa Inggris, 12 anak dari kelas A1 dan 13 anak dari A2 di TK Santa Maria Banjarmasin. Teknik pengumpulan data dalam penelitian ini adalah observasi teknik ini digunakan untuk melihat bagaimana strategi pegenalan bahasa Inggris pada anak usia dini di TK Santa Maria Banjarmasin, wawancara digunakan untuk mendapat informasi tentang pengenalan bahasa Inggris di TK Santa Maria Banjarmasin,dan dokumentasi teknik ini digunakan untuk mendapatkan dokumen-dokumen pendukung. Data yang diperoleh selanjutnya dianalisis menggunakan Milles dan Huberman yang dilakukan secara interaktif dengan tahap pengumpulan data berupa tahap reduksi, tahap penyajian data, dan tahap kesimpulan data dalam bentuk pengkodean. Pengecekan keabsahan dalam penelitian ini berupa perpanjangan pengamatan, ketekunan pengamatan dan triangulasi.

\section{HASIL DAN PEMBAHASAN \\ HASIL}

Penyajian data yang dipaparkan dalam penelitian ini berupa deskripsi data yang akan disajikan untuk menggambarkan keadaan data dalam bentuk uraian atau kalimat mengenai strategi pengenalan Bahasa Inggris yang di TK Santa Maria Banjarmasin yang meliputi metode, materi, media dan peneilaian. Metode pembelajaran yang dipergunakan pada saat melakukan kegiatan pengenalan bahasa Inggris seperti bernyanyi, bermain, dengar dan ulangi, tanya jawab dan make a match. Media yang digunakan adalah media pandang dan lembar kerja. Materi mengenalkan Bahasa Inggris kepada anak di sekolah ini menyesuaikan dengan kebijakan sekolah ada beberapa tema yang dikenalkan seperti anggota tubuh, orang-orang yang ada di rumah, binatang, makanan sehat dan natal. Penilain yang digunakan adalah observasi, hasil karya, percakapan dan anekdot.

\section{PEMBAHASAN}

Penelitian ini bertujuan untuk mengetahui bagaimana strategi pengenalan bahasa Inggris pada anak usia dini di TK Santa Maria Banjarmasin, penelitian ini merupakan penelitian kualitatif deskriptif dengan rancangan analisis Milles dan Huberman.

1. Metode yang digunakan guru selama pengenalan bahasa inggris di TK Santa Maria Banjarmasin: a. Metode TPR (Total Physical Response Method) adalah metode pengajaran bahasa yang didasarkan pada pendekatan pemahaman dan meyerupai pembelajaran bahasa secara alamiah, metode ini yang digunakan guru bahasa Inggris dalam mengucapkan setiap kosakata, menurut metode 


\begin{tabular}{|c|c|c|}
\hline \multicolumn{4}{|c|}{ Jurnal Warna : Jurnal Pendidikan Dan Pembelajaran Anak Usia dini. } \\
September 2020.Vol 05. No. 02 \\
\hline Received: Agustus 2020 & Accepted: Agustus 2020 & Published: September 2020 \\
\hline & Article DOI: $10.24903 / j w . v 5 i 2.525$ \\
\hline
\end{tabular}

ini belajar bahasa kedua serupa dengan anak mempelajari bahasa ibunya,yaitu dengan sinkronisasi antara bahasa dengan gerak tubuh. Sebagaimana yang dikemukakan oleh Ricards dan Rogers (M.F Sri Ekonomi, 2007:73) pembelajaran bahasa dengan metode ini dilakukan dengan cara memberikan rangsangan yang berupa perintah-perintah dalam bahasa tujuan yang direspon oleh siswa dengan tindakan fisik sebagai pelaksanaan perintahperintah. Sesuai dengan karakteristik anak usia dini pada umumnya adalah pembelajar yang merupakan pemikir aktif, mereka senang belajar sesuatu, termasuk juga belajar bahasa dengan cara melakukan sesuatu (Kasihani K.E. Suyanto, 2007:20). Ketika anak mempelajari sesuatu mereka akan lebih cepat mengingingatnya jika dibarengi dengan gerakan-gerakan yang bermakna yang sesuai dengan hal-hal yang ingin mereka pelajari, melakukan dengan gerakan lebih mudah diingat oleh anak dibanding dengan hanya duduk diam dan mendengarkan. Seperti yang peneliti lihat ketika melakukan observasi di TK Santa Maria Banjarmasin, ketika menyampaikan materi menyampaikan materi terkait kosakata baru dalam pengucapannya selalu menggunakan mimik wajah dan gerak anggota tubuh yang sangat jelas dengan demikian anak-anak sangat mudah dalam mengikuti dan mengucapkan kosakata tersebut. Anggota tubuh yang digunakan dan disesuaikan oleh guru Bahasa Inggris di TK Santa Maria Banjarmasin ketika melakukan metode TPR untuk kegiatan pembelajaran adalah: 1) Mulut, pada saat mengucapkan kata harus jelas. 2) Tangan, gerakan yang dilakukan oleh tangan sesuai dengan apa yang ingin diucapkan.3) Badan, gestur badan harus menyesuaikan de dengan gerak tangan dan yang diucapkan oleh mulut. Berdasarkan dengan penelitian penggunaan metode TPR (Total Physical Response) yang dilakukan guru dalam pengenalan bahasa Inggrs ber tujuan agar anak lebih jelas dalam memahami maksud yang disampaikan oleh guru, sehingga setiap kosakata yang disampaikan dapat dimengerti oleh anak. b. Metode Nyanyian dan Lagu (Sing and Song) merupakan suatu kegiatan yang sangat disukai oleh anak-anak. Secara umum menyanyi bagi anak lebih berfungsi sebagai aktivitas bermain dari pada aktivitas pembelajaran atau penyampaian pesan, menyanyi dapat memberikan kepuasan, kegembiraan, dan kebahagiaan bagi anak sehingga anak dapat termotivasi untuk belajar lebih giat. Metode nyanyian dan lagu adalah salah satu metode pengenalan Bahasa Inggris di TK Santa Maria Banjarmasin yang digunakan ketika awal pertemuan dan ketika selesai pengenalan kosakata, ada beberapa lagu yang dinyanyikan dalam setiap pertemuan, yaitu: 1) Hello Hello How Are You. 2) My House. 3) Family Finger. 4) Head,Shoulder, Knees and Toes. 5) Finger Song. 6) Five Little Duck 7) Bingo. 8) NamaNama Binatang . 9) We Wish You a Marry Christmas. Berkaitan dengan lagu-lagu yang dipergunakan dalam kegiatan pembelajaran. Menurut Bumpass (M.F Sri Ekonomi, 2007:94) menyatakan adanya dua faktor yang menentukan keberhasilan pemanfaatan lagu untuk mengajar Bahasa Inggris kepada siswa usia dini yaitu: 1) Pemilihan lagu yang dapat menjawab kebutuhan emosional siswa dan 


\begin{tabular}{|c|c|c|}
\hline \multicolumn{4}{|c|}{ Jurnal Warna : Jurnal Pendidikan Dan Pembelajaran Anak Usia dini. } \\
September 2020.Vol 05. No. 02 \\
\hline Received: Agustus 2020 & Accepted: Agustus 2020 & Published: September 2020 \\
\hline & Article DOI: $10.24903 / j w . v 5 i 2.525$ \\
\hline
\end{tabular}

menarik secara intelektual. 2) Perencanaan kegiatan pembelajaran yang memanfaatkan lagu agar dapat memenuhi beberapa persyaratan seperti: menyenangkan dapat mempertahankan minat, dapat digunakan sebagai alat bantu untuk belajar melafalkan bunyi-bunyi baru, membantu pembelajaran kata-kata dan dramatisasi yang cocok. Dari beberapa lagu yang dinyanyikan dalam kegiatan pembelajaran bahasa Inggris di TK Santa Maria Banjarmasin semuanya sesuai dengan pendapat Bumpass yang mana lagulagu tersebut dapat menjawab emosional anak dan menyenangkan sehingga dapat mempertahankan minat anak dalam pembelajaran dan dapat membantu anak melafalkan kosakata baru untuk pembelajaran kata-kata. c. Metode Tanya dan Jawab merupakan kegiatan yang dilakukan oleh guru ketika melakukan pengenalan bahasa Inggris di TK Santa Maria Banjarmasin. Metode ini merupakan teknik yang sangat dikenal dalam kehidupan sehari-hari, untuk tingkat anak usia dini guru dapat memulai bertanya kepada anak dan memberikan contoh jawabannya, kemudian siswa menirukan setelah itu guru bertannya kembali tentang kosakata yang dicontohkan tadi, sebelum menjawab pertanyaan anak-anak harus mendengarkan dan memahami pertanyaan tersebut. Seperti yang peneliti lihat ketika melakukan observasi pengenalan bahasa Inggris di TK Santa Maria menggunakan metode tanya jawab ketika mengenalkan kosakata baru atau mengulang kosakata yang dipelajari minggu sebelumnya. Sesuai dengan teori Piaget dan Vygotsky (Devinta Puspita Putri,2018:34) disebutkan bahwa kebiasaan belajar anak usia dini adalah dengan menghubungkan antara apa yang mereka ketahui dan apa yang mereka dengarkan, mengingat pada masa usia dini anak-anak masih sangat mudah dalam mengingat dan suka menirukan segala sesuatu yang ada disekitarnya. d. Metode Dengar dan Ulangi adalah salah satu metode pengenalan Bahasa Inggris yang digunakan oleh guru di TK Santa Maria, yang mana guru mengucapkan sesuatu dan murid mendengarkan kemuadian guru mengatakan lagi dan anak-anak diminta untuk mengulang kosakata yang diucapkan oleh guru tersebut. Sesuai dengan pendapat menurut Sharpe (Devinta Puspita Putri,2018:33) keterampilan berbicara dan mendengarkan anak usia dini merupakan pembelajaran efektif dalam pemerolehan bahasa. Menurut Penfield dalam teori mekanisme otak (theory of brain mechanism) (M.F Sri Ekonomi, 2007:3) "Masa usia dini merupakan masa yang paling ideal untuk belajar bahasa selain bahasa ibu (bahasa pertama)". Alasannya karena, pada usia dini otak anak masih plastis dan fleksibel, sehingga proses penyerapan bahasa lebih mulus. Selain itu, daya penyerapan bahasa pada anak berfungsi secara otomatis, karena pada usia yang lebih dari itu otak akan menjadi lebih keras, lambat dan kurang bisa menerima rangsangan bahasa, karena otak lebih siap dengan tugas yang lain. Karena itu guru harus bisa mengucapkan kosakata dengan baik dan benar agar anak dapat mengucapkan kosakata dengan baik dan benar, anak akan meniru apa yang didengarnya, sesuai dengan pendapat Bumpass (M.F Sri Ekonomi, 2007:2) bahwa anak-anak memiliki dua sifat yang sangat 


\begin{tabular}{|c|c|c|}
\hline \multicolumn{4}{|c|}{ Jurnal Warna : Jurnal Pendidikan Dan Pembelajaran Anak Usia dini. } \\
September 2020.Vol 05. No. 02 \\
\hline Received: Agustus 2020 & Accepted: Agustus 2020 & Published: September 2020 \\
\hline & Article DOI: $10.24903 / j w . v 5 i 2.525$ \\
\hline
\end{tabular}

bermanfaat untuk membantu mereka belajar bahasa asing. Pertama, mereka memiliki ingatan dan persepsi yang tajam, mereka dapat belajar melafalkan bunyi dengan cepat dan tepat dan dapat menguasai apa yang baru dipelajari tanpa kesulitan. Kedua, anak tidak mempunyai hambatan yang berarti sehingga dapat memberikan respon dengan sangat mudah dan dilakukan mereka di luar kesadaran. e. Metode Bermain adalah salah satu meode yang digunakan ketika pengenalan bahasa Inggris, menurut Widiputera (M. Yamin, 2017:92) banyak metode dan teknik yang dapat digunakan, diantaranya melalui: 1) Story Telling (Bercerita). 2) Role Play (Bermain Peran). 3) Art and Crafts (Seni dan Kerajinan Tangan) 4) Games (Permainan) 5) Show and Tell 6) Music and Movement (Gerak dan Lagu) dimana termasuk di dalamnya singing (Nyanyian). Seperti yang peneliti lihat ketika melakukan observasi di TK Santa Maria guru menggunakan metode bermain melalui listen and draw dan Music and Movement (Gerak dan Lagu) dimana termasuk di dalamnya singing (Nyanyian), pada kegiatan listen and draw kegiatan ini ditambah dengan kegiatan mewarnai(Kasihani K.E. Suyanto, 2007:91) yang mana kegiatan mewarnai termasuk dalam seni dan kerajinan tangan (Art and Crafts), sebelum bermain ibu akan memberikan contoh bagaimana aturan bermainnya, Sesuai dengan pendapat Khan (Kasihani K.E. Suyanto, 2007:118) bahwa permainan adalah aktivitas yang dilakukan berdasarkan aturan tertentu. Salah satu kegiatan listen and draw yang peniliti lihat di TK Santa Maria adalah, guru akan memberikan contoh bagaimana cara bermainnya terlebih dahulu, seperti mengenalkan warna dalam bahasa Inggris ibu akan memberikan gambar untuk diwarnai, disamping gambar tersebut ada kode bahwa bagian nomor satu berwarna pink, maka anak akan memberikan warna pink pada bagian yang bernomor satu tersebut, sebelum itu ibu akan mengatakan "number one is pink", maka anakanak harus paham dengan peraturan perintah tersebut. Selain listen and draw di TK Santa Maria juga menggunakan metode bermain melalui Music and Movement (gerak dan lagu), guru akan mengajak anak menyanyikan lagu sambil bergerak, gerakan harus sesuai dengan lagu yang dinyanyikan, lagu yang dinyanyikan melalui metode bermain Music and Movement adalah Finger Song, Head, Shoulder, Knees and Toes, Bingo dan My House. f. Metode Make a Match sebagaimana yang dikemukakan oleh Isjoni (Helda Yeti,2018:21) bahwa make a match merupakan model pembelajaran mencari pasangan sambil belajar konsep dalam suasana yang menyenangkan. Di TK Santa Maria juga menggunakan metode ini melalui media lembar kerja yang mana anak anak akan diberikan gambar yang bersebelahan sehingga anak harus mencari pasangan yang benar, Menurut Slameto sebagaimana dikutip oleh Siroj, keberhasilan pembelajaran dapat ditentukan oleh strategi dan pendekatan yang digunakan oleh guru. Ada beberapa model pembelajaran yang dapat mengembakan motivasi belajar pada anak salah satunya model cooperative learning tipe make a match. Model pembelajaran ini memberi motivasi belajar yang tinggi bagi siswa karena mengandung unsur permainan. 


\begin{tabular}{|c|c|c|}
\hline \multicolumn{3}{|c|}{ Jurnal Warna : Jurnal Pendidikan Dan Pembelajaran Anak Usia dini. } \\
September 2020.Vol 05. No. 02 \\
\hline Received: Agustus 2020 & Accepted: Agustus 2020 & Published: September 2020 \\
\hline & Article DOI: $10.24903 / j w . v 5 i 2.525$ \\
\hline
\end{tabular}

2. Materi yang digunakan guru selama pengenalan bahasa Inggris di TK Santa Maria Banjarmasin pada saat peneliti melakukan penelitian selama beberapa kali yang berkaitan dengan pembelajaran bahasa Inggris di kelompok A ada beberapa materi yang diangkat pada hari tersebut yaitu: a. Senin, 09 September 2019, materi pada hari ini adalah tentang lingkunganku, membahasa tentang siapa saja yang ada di rumah, kosakata yang dikenal ada lima yaitu: Daddy Ayah, Mommy Ibu, Brother Saudara Laki-Laki, Sister Saudara Perempuan, Little Baby Bayi Kecil, b. Senin, 16 September 2019, materi pada hari ini adalah tentang Diriku yang mana pada materi ini membahas tentang anggota tubuh, selain itu materi lingkunganku juga dikenalkan pada hari itu, karena hari itu anak-anak hanya mengulang pengenalan Bahasa Inggris sebelumnya. bu Reka mengenalkan 11 kosakata tentang anggota tubuh yaitu Head, Shoulders, Knees, Toes, Eyes, Ears, Mouth, Nose, Feet, Hands, Tongue, ibu Reka mengenalkan orang-orang yang ada di Rumah, ada lima kosakata yang dikenalkan hari ini yaitu: Daddy Ayah, Mommy Ibu, Brother Saudara Laki-Laki, Sister Saudara Perempuan, Little Baby Bayi Kecil. c. Senin, 23 September 2019, materi pada hari ini adalah tentang kebutuhanku membahas tentang makan sehat, ibu Reka mengenalkan 11 kosakata, enam tentang makanan sehat dan enam makanan tidak sehat yaitu: Beans, Strawberry, Carrot, Fish, Broccoli, Avocado, untuk makanan sehat sedangkan untuk makanan tidak sehat kosakatanya: Fries, Candy ,Cookie, Candy Cane, Soda, Cake. d. Senin, 30 September 2019, materi pada hari ini adalah tentang Binatang ibu Reka mengenalkan Bahasa Inggris tentang binatang dengan menyanyi yaitu menyanayikan lagu Five Little Duck dan Binggo. e. Senin,07 Oktober 2019, materi pada hari ini adalah tentang binatang peliharaan ibu Reka mengenalkan enam kosakata yaitu: Cat, Dog, Cow, Chicken, Duck, Fish. f. Senin, 21 Oktober 2019, materi pada hari ini adalah tentang tentang Binatang, kosakta yang ulang ada tujuh yaitu : Dog, Cat, Cow, Butterfly, Duck, Fish, Chicken dan mengulang lagu yang sudah dikenalkan sebelumnya pada materi bintang yaitu Five Little Duck, Binggo,dan nama-nama binatang. g. Senin, 04 November 2019, materi pada hari ini adalah tentang tenang Natal (Christmas). Materi pengenalan Bahasa Inggris yang disampaikan kepada anak-anak di TK Santa Maria sesuai dengan pendapat Hurlock (Nor Izatil Hasanah, 2015:67) bahwa anak-anak lebih dahulu mempelajari kata-kata yang dibutuhkanya, dapat dilihat dari beberapa materi diatas kosakata yang disampaikan dibutuhkan anak untuk kesehariannya, sedangkan menurut Ekonomi (M.F Sri Ekonomi, 2007:119) bahwa kata atau frase yang diperkenalkan kepada anak hendaknya dalam bentuk yang paling sederhana. Kesederhanan ini bisa dilihat dari kata atau frasa yang diperkenalkan dan jumlah kata atau frasa yang diperkenalkan kepada anak, untuk kosakta yang dikenalkan ketika pengenalan Bahasa Inggris di TK Santa Maria setiap minggunya kepada anak-anak memang berbeda, ada yang lima kosakata, maksimalnya kosakata yang dikenalkan dengan anak memang lima kosakata, sedangkan ada yang 


\begin{tabular}{|c|c|c|}
\hline \multicolumn{4}{|c|}{ Jurnal Warna : Jurnal Pendidikan Dan Pembelajaran Anak Usia dini. } \\
September 2020.Vol 05. No. 02 \\
\hline Received: Agustus 2020 & Accepted: Agustus 2020 & Published: September 2020 \\
\hline & Article DOI: $10.24903 / j w . v 5 i 2.525$ \\
\hline
\end{tabular}

mengenalkan sebelas kosakata, tetapi kosakata tersebut akan diulang lagi dipengenalan Bahasa Inggris selanajutnya dan untuk anak dapat tetap mengingat kosakata tersebut biasanya digunakan metode menyanyi. Menurut Nurhadi (Nor Izatil Hasanah, 2015:67) juga menyarankan beberapa kosakata bahasa Inggris yang sesuai dengan tingkat perkembangan anak usia dini antara lain: a. Names of colours ( Nama-namaWarna ) b. Numbers up to ten ( Angka satu sampai sepuluh) c. Family ( keluarga)d. Animals (Binatang) e. Fruits and Vegetables (Buah-buahandan sayur-sayuran) f. Parts of the body (Anggota tubuh) g. I am / You are h. There is / there are i. I like / I don't like. Dapat dilihat dari materi yang dikenalkan kepada anak-anak sesuai denga pendapat Nurhadi yang mana ibu Reka mengenalkan materi tentang keluarga, binatang, dan anggota tubuh, materi ini sesuai dengan perkembangan anak yang mana kosakata tersebut dekat dengan anak dan diperlukan dalam keseharian anak, materi yang dikenalkan juga sederhana.

3. Media yang digunakan guru selama pengenalan bahasa Inggris yang sering digunakan ketika pengenalan bahasa Inggris di TK Santa Maria adalah: a. Media Pandang/Visual adalah media yang dapat dipandang atau dilihat dan dapat disentuh oleh siswa ataupun anak-anak, misalnya seperti gambar, foto, benda sesungguhnya, peta, miniatur, dan realia. Media pandang yang paling banyak digunakan guru antara lain adalah gambar, flash cards, dan benda nyata (banana, mango, dictionary, etc) (Kasihani K.E. Suyanto, 2007:103). Menurut Kasihani Suyanto (Kasihani K.E. Suyanto, 2007:109) ukuran gambar untuk media pandang adalah ukuran besar, biasanya menggunakan kertas yang agak tebal, kaku, dan ukurannya A4 seperti yang peneliti lihat ketika observasi di TK Santa Maria sudah sesuai dengan pendapat Kasihani, media yang digunakan di TK Santa Maria biasanya berupa gambar berukuran A4. b. Lembar Kerja merupakan media yang juga selalu digunakan ketika kegiatan pembelajaran. Pada lembar kerja yang dibagikan biasanya akan ada berupa gambar yang dilengkapi gambar untuk diwarnai anak-anak selain mewarna juga sering digunakan untuk mencocokkan gambar yang sudah disediakan jadi tugas anak adalah mencocokkan antara gambar sebelah kanan dan sebelah kiri. Menurut Kasbolah dalam (Kasihani K.E. Suyanto, 2007:100)untuk dapat menarik perhatian anak, perlu diciptakan situasi kelas yang membuat anak termotivasi untuk belajar. Salah satu cara membuat kelas lebih menarik adalah dengan penggunaan alat bantu mengajar atau media ketika guru mengajar. Berdasarkan paparan diatas tentang kriteria media pembelajaran yang diharuskan untuk anak usia dini, penggunaan media yang digunakan oleh guru untuk mengenalkan bahasa Inggris untuk anak tidak menggunakan media pembelajaran APE tetapi media-media yang digunakan sudah sesuai baik dari ketetapan penggunaan media dengan materi pembelajaran, kemudahan memperoleh media, keterampilan guru dalam mengolah media dan tujuan yang ingin dicapai itu sudah cukup sesuai dengan yang dianjurkan. 4. Penilaian yang digunakan guru selama pengenalan bahasa Inggris TK Santa Maria Banjarmasin adalah: a. Penilaian dengan Cara 


\begin{tabular}{|c|c|c|}
\hline \multicolumn{4}{|c|}{ Jurnal Warna : Jurnal Pendidikan Dan Pembelajaran Anak Usia dini. } \\
September 2020.Vol 05. No. 02 \\
\hline Received: Agustus 2020 & Accepted: Agustus 2020 & Published: September 2020 \\
\hline & Article DOI: $10.24903 / j w . v 5 i 2.525$ \\
\hline
\end{tabular}

Observasi adalah pengumpulan data/informasi melalui pengamatan langsung maupun tidak langsung terhadap sikap dan perilaku anak, observasi dilakukan selama kegiatan pembelajaran berlangsung (Anik Lestariningru, 2017:98), ibu Reka akan mengamati bagaimana anak berinteraksi ketika pengenalan Bahasa Inggris, apakah anak mampu mengucapkan kosakata Bahasa Inggirs dan bernyanyi dalam Bahasa Inggris maupun berdo'a dalam Bahasa Inggris. b. Penilaian dengan Cara Hasil Karya adalah hasil kerja anak-anak didik setelah melakukan suatu aktivitas seperti: mengerjakan pekerjaan tangan atau karya seni seperti: melipat, menggambar, membentuk dari plastisin, membuat topi dari bahas bekas dan lain-lain (Anik Lestariningru, 2017:101). Hasil karya yang dikerjakan anak-anak ketika pengenalan Bahasa Inggris di TK Santa Maria Banjarmasin berbentuk lembar kerja yaitu seperti: melakukan mewarnai gambar, menyambung titik putus putus, dan matching. c. Penilaian dengan Percakapan merupakan penilain yang dilakukan melalui bercakapcakap antara anak dan pendidik baik dalam kelas atau luar kelas, penilaian ini digunakan pada saat kegiatan terpimpin atau bebas (Anik Lestariningru, 2017:99). Penilaian ini bisa digunakan ketika guru bertanya tentang kosakata kepada anak, , biasanya ibu Reka akan bertanya apa arti dari kosakata tersebut atau bertanya tentang kabar anak, dan mengucapkan selamat pagi dengan penilain ini dapat megetahui apakah anak dapat mengingat kosakata yang telah dikenalkan sebelumnya.d. Pencatatan Anekdot merupakan teknik penilaian yang dilakukan dengan mencatat sikap dan perilaku khusus pada anak terkait perkembangan yang negative atau positif yang terjadi terkait proses pertumbuhan dan perkembangannya. Catatan anekdot harus kejadian factual yang sesuai kejadian yang ditulis, tidak boleh menggunakan persepsi pendidik (Anik Lestariningru, 2017:98). Pencatatan anekdot dilakukan untuk mengatahui bagaimana perilaku ana-anak ketika pengenalan Bahasa Inggris di dalam kelas, apakah anak tersebut dapat memperhatikan guru ketika pengenalan Bahasa Inggris. Berdasarkan paparan di atas penilain di TK Santa Maria sudah sesuai dengan ketetapan penilain dan sudah dapat mengukur tingkat penguasaan anak-anak sesuai dengan pendapat McKay (Devinta Puspita Putri,2018:107) penting bagi anak untuk terlibat dalam penilain untuk mengetahui seberapa besar anak dapat merefleksikan pengetahuannya yang ia dapat.

\section{PENUTUP}

\section{Kesimpulan}

Berdasarkan analisis data penelitian tentang strategi pengenalan Bahasa Inggris di TK Santa Maria Banjarmasin dapat diperoleh kesimpulan bahwa 1) Metode yang sering digunakan dalam setiap kegiatan pengenalan bahasa Inggris adalah metode menyanyi, bercerita, bermain dan TPR (Total Physical Response). Nyanyian dan Lagu, Tanya Jawab, Dengar dan Ulangi. 2) Materi yang digunakan adalah tentang pengenalan beberapa kosakata dimana disetiap pertemuan akan diulangkan dan akan ada kosakata baru yang dikenalkan seperti seperti kosakata tentang Binatang. 3) Media yang sering digunakan adalah media 


\begin{tabular}{|c|c|c|}
\hline \multicolumn{3}{|c|}{ Jurnal Warna : Jurnal Pendidikan Dan Pembelajaran Anak Usia dini. } \\
September 2020.Vol 05. No. 02 \\
\hline Received: Agustus 2020 & Accepted: Agustus 2020 & Published: September 2020 \\
\hline & Article DOI: $10.24903 / j w . v 5 i 2.525$ \\
\hline
\end{tabular}

pandang atau visual, dengan media ini anak dapat melihat gambar kosakata yang akan dikenalkan , sedangkan media lembar kerja digunakan untuk melakukan mewarnai gambar, menyambung titik putus putus, dan matching. 4) Penilaian yang digunakan di TK Santa Maria Banjarmasin adalah dengan observasi atau pengamatan langsung,percakapan, pencatatan anekdot dan hasil karya ketika pengenalan Bahasa Inggris, hasil karya untuk digunakan untuk mewarnai gambar, menyambung titik putus putus, dan matching. Sedangkan pencatatan anekdot digunakan untuk mengetahu sikap anak ketika pengenalan Bahasa Inggris.

\section{SARAN}

Berdasarkan analisa diatas, maka peneliti memberikan saran kepada pihak yang berkepentingan yang sekiranya dapat dijadikan sebagai bahan pertimbangan dalam pengenalan bahasa asing di sekolah:

1. Bagi pihak sekolah sudah memfasilitasi kebutuhan pembelajaran dengan menyediakan segala sarana dan prasarana yang menunjang kegiatan pengenalan bahasa Inggris di sekolah contohnya seperti media pembelajaran yang sudah ada di sekolah.

2. Dalam kegiatan di dalam kelas guru yang mengenalkan bahasa Inggris sudah menggunakan strategi yang bervariasi mungkin untuk selanjutnya lebih ditingkatkan lagi untuk memperbaharui strategi pembelajaran dan hendaknya mengupayakan dalam setiap kegiatan pembelajaran menggunakan media dan metode pembelajaran yang lebih bervariasi agar membuat anak aktif dalam mengikuti kegiatan pembelajaran.

\section{DAFTAR PUSTAKA}

Devinta Puspita, Iswahyuni,dkk., (2018). Mengajar Bahasa Inggris Untuk Anak Usia Dini,Malang: UB Press.

Ekonomi, M.F Sri,. (2007). Bahasa Inggris Untuk Anak Usia Dini. BanjarmasinJogjakarta: PBS FKIP Unlam-Ircisod.

Hasanah, Nor Izatil,. (2015) "Pengembangan Permainan Sing; Show; And Guess Dengan Media Flashcards Untuk Memperkenalkan Perbendaharaan Kata Bahasa Inggris Pada Anak TK Kelompok A", Tesis; Program Pascasarjana Universitas Negeri Surabaya.

Helmawati,. (2015). Mengenal dan Memahami $P A U D$, Bandung: PT Remaja Rosdakarya.

Kartinah, Titin,. (2018) "Pengenalan Bahasa Inggris Melalui Metode storytelling Berbantu Media Gambar Pada Anak Usia 5-6 Tahun Di Tk Purnama Sukarame Bandar Lampung", Skripsi, Universitas Raden Intan Lampung, Jurusan PIAUD.

Lestariningrum, Anik,. (2017) "Perencanaan Pembelajaran Anak Usia Dini”, Kediri: Adjie Media Nusantara.

Putri, Rizka Isnaani,. (2018) "Peningkatan Penguasaan Kosakata Bahasa Inggris dengan Metode Bernyanyi pada Kelompok B Taman Kanak-Kanak Anak Sholeh Sukodono Sidoarjo", Skripsi, Sunan Ampel Surabaya, Jurusan PIAUD

Suyanto , Kasihani K,E,. (2010) English for Young Learners, Jakarta: Bumi Kasara.

Uzer, Yas Vernandes,. (2019) "Strategi Belajar Bahasa Inggris yang Menyenangkan untuk Pendidikan Anak Usia Dini", Jurnal, Univ.PGRI Palembang.

Yamin, M,. (2017) "Metode Pembelajaran Bahasa Inggris di Tingkat Dasar", dalam Jurnal Pesona Dasar Universitas Syiah Kuala.

Yeti, Helda,.(2018) Penerapan Model Pembelajaran Kooperatif Tipe Make A Match Untuk Mengembangkan Motivasi Belajar Anak Usia Dini Usia 7- 
Jurnal Warna : Jurnal Pendidikan Dan Pembelajaran Anak Usia dini. September 2020. Vol 05. No. 02

8 Tahun Di Sd Negeri 1 Way Dadi Sukarame Bandar Lampung, Skripsi, Universitas Negeri Raden Intan Lampung, Jurusan Pendidikan Islam Anak Usia Dini. 